\title{
A student right of audience? Implications of law students appearing in court
}

\section{Susan C ampbell*}

This article examines the policy considerations underlying the common law limitation of the right of audience in the courts to professionally qualified and regulated advocates. It discusses the program conducted by $M$ onash $U$ niversity in A ustralia whereby law students regularly represent their clients in court and analyses the safeguards built into this program in an attempt to meet those policy considerations. Finally the article looks briefly at the intriguing question of whether student advocates might be immune from liability for negligence, since that immunity still applies in A ustralia.

\section{PART I The common law right of audience}

The common law principle that only professionally qualified lawyers are entitled to represent litigants in court is deeply embedded in English and Australian legal consciousness. Judith Dickson ${ }^{1}$ has traced the origins of this principle back as early as the late fourteenth century but contemporary courts in both jurisdictions usually begin a discussion of the principle with reference to C ollier v H icks² where Lord Tenterden CJ said "the Superior Courts do not allow every person to interfere in the proceedings as an advocate but confine that privilege to gentlemen admitted to the Bar by the members of one of the Inns of Court" 3 and Parke J referred to the "ancient usage" whereby "persons of a particular class are allowed to practise as advocates". 4

A snapshot of cases across the succeeding one hundred and seventy years shows the courts upholding this principle without question. In Tritonia L td v Equity and L aw Life A ssurance Society 5 Viscount Simon LC referred to the rule "limiting a right of audience on behalf of others to

I am grateful for the comments of the member of the Editorial Board who acted as referee for this article.

$M$ y thanks also to my research assistant, Safeera A bdul Wahid.

*Professional Fellow in Legal Practice, Faculty of Law, $M$ onash U niversity, Victoria, A ustralia

Susan C ampbell is D irector of L egal Practice Programs at $M$ onash $U$ niversity and runs, among other things, the $L$ aw Faculty's clinical legal education program.
1 Dickson J, "Students in C ourt: C ompetent and Ethical A dvocates" (1998) vol 16(2) Journal of Professional $L$ egal Education 155 at p.158

2 (1831) 2 B. \& A d. 663; 109 ER 1290

3 ibid at $668 ; 1292$

4 ibid at $671 ; 1293$

5 [1943] A C 584 
members of the English or Scottish or N orthern Irish Bars" 6 and in A bse v Smith ${ }^{7}$ Lord D onaldson M R went so far as to say "Limitation of the categories of persons whom courts are prepared to hear as advocates for parties to proceedings before them is, so far as I know, a feature of all developed systems for the administration of justice." 8

In A ustralia both State and Federal courts have unhesitatingly applied the principle, the most recent example being the decision of the $\mathrm{N}$ ew South Wales Court of A ppeal in D amjanovic v M aley. ${ }^{9}$

The emergence in the 1970's of the concept of the "M cKenzie friend" might be thought to have represented an inroad into the profession's monopoly on the right of audience. However it is clear from $M$ cKenzie and subsequent cases that the role of a $M$ cKenzie friend does not include the right to address the court. In M CK enzie v M cK enzie10 itself Davies LJ11 quoted the words of Lord Tenterden CJ in Collier v H icks that any one may attend court "as a friend of either party, may take notes, may quietly make suggestions, and give advice but no one can demand to take part in the proceedings as an advocate." 12

Recent English cases (which may reflect a trend toward the increasing use of lay advocates) reinforce the limits on the activities of a $\mathrm{M}$ cKenzie friend. They go on to assert a court's power to control and if necessary to banish a M cKenzie friend whose conduct disrupts the proceedings. In $R$ v Bow C ounty C ourt ex $p$ Pelling ${ }^{13}$ Lord Woolf gave as an example the friend indirectly running the case and using the litigant as a puppet. Staughton LJ in R v L eicester C ity J ustices ex p Barrow ${ }^{14}$ cited conduct such as wasting time as by prompting the litigant to ask irrelevant questions.

W hatever the behaviour of a McKenzie friend, it is clear that the role in fact reinforces the common law limitation on the right of audience.

The principle is largely mirrored, rather than altered, by statute ${ }^{15}$ A ustralian legislation governing the jurisdiction and procedure in each court generally provides that a party to proceedings before the court may appear either personally or by a legal practitioner. It is worth noting that, even in those States where the profession was formerly divided, the legislation frequently gave both branches of the profession a right of audience. For example, the $\mathrm{N}$ ew South W ales $\mathrm{D}$ istrict C ourt A ct 1973 provides that "A party to any proceedings may appear by a barrister or solicitor retained by or on behalf of that party." 16

In those States where the profession is legally fused, such as Victoria, the distinction between barristers and solicitors is of course irrelevant (although it is not entirely unknown for some judges to be "unable to hear" a solicitor seeking to appear before them).

The recent extension of the right of audience to solicitors in England and $W$ ales, through the C ourts and L egal Services A ct 1990 and the A ccess to J ustice A ct 1999, brings A ustral ian and English jurisdictions broadly into line but in neither case does the relevant legislation affect the underlying common law principle prohibiting unqualified advocates.

$\begin{array}{llll}6 & \text { ibid at 587 } & 12 & \text { (1831) 2 B.\& A d. } 663 \text { at 668; } 109 \text { ER } 1290 \text { at } 1292 \\ 7 & \text { [1986] 2 W LR 322 } & 13 & \text { [1999] 4 A II ER 751 } \\ 8 & \text { ibid at 326 } & 14 \text { [1991] 2 Q B 260 } \\ 9 & \text { [2002] N SW CA 230 } & 15 \text { apart from minor inroads such as that effected by the } \\ 10 & \text { [1971] P 33 } & \text { Lay Representatives (Rights of A udience) O rder } 1992 \\ 11 & \text { ibid at 38 } & 16 \text { s.43 }\end{array}$


W hile the courts have consistently maintained the right of audience principle, the policies put forward to justify it vary considerably (as is often the case in reasoning based on the public interest). O ne might reasonably assume that the paramount consideration should be the protection of the litigant from incompetent advocacy, and this is indeed one of the bases on which the principle is founded. But in Tritonia 17 the only consideration relied upon by the House of Lords was the assistance to the court itself which trained advocates provide.

One might also expect numerous references to the complexities of litigation, which cannot properly be handled by untrained advocates. But in Collier v H icks 18 itself Lord Tenterden CJ said that it was to the benefit of the parties that they should not be represented at all, otherwise they might be put to "heavy and grievous expense" and that it was in the interests of justice, at least in summary proceedings, to hear only the parties themselves, "without that nicety of discussion, and subtlety of argument, which are likely to be introduced by persons more accustomed to legal questions". 19

Some courts are concerned that an untrained advocate might "cause the litigant loss",20 which suggests that the judges had forgotten that, in Australia at least, a client has no right to sue an incompetent professional advocate for any loss caused by the latter's negligence.

In addition to a general concern for the competence of advocates, whether for the assistance of the court or in the interest of the litigant, the other consideration most referred to is the issue of "probity", that is, that an admitted practitioner as an officer of the court owes clearly recognised duties to the court and to the administration of justice and in certain situations such duties take precedence over the client's own interests. This policy is put most forcefully by D onaldson M R in A bse $v$ Smith 21 and is worth quoting at length.

"But quite apart from the public interest in ensuring that advocates appearing in the courts have the requisite standard of skill, there is another and even more important requirement......This is the requirement of absolute probity. The public interest requires that the courts shall be able to have absolute trust in the advocates who appear before them. The only interest and duty of the judge is to seek to do justice in accordance with the law. The interest of the parties is to seek a favourable decision and their duty is limited to complying with the rules of court, giving truthful testimony and refraining from taking positive steps to deceive the court. The interest and duty of the advocate is much more complex, because it involves divided loyalties. He wishes to promote his client's interest and it is his duty to do so by all legitimate means. But he also has an interest in the proper administration of justice, to which his profession is dedicated, and he owes a duty to the court to assist in ensuring that this is achieved. The potential for conflict between these interests and duties is very considerable, yet the public interest in the administration of justice requires that they be resolved in accordance with established professional rules and conventions and that the judges shall be in a position to assume that they are being so resolved. There is thus an overriding public interest in the maintenance amongst

17 note 5 above

18 note 2 above

19 ibid at 668
20 per Stein JA in D amjanovic v M aley note 9 above: " $L$ ay advocates are unqualified, unaccredited and uninsured" at para 79

21 note 7 above 
advocates not only of a general standard of probity, but of a high professional standard, involving a skilled appreciation of how conflicts of duty are to be resolved." 22

This statement of the advocate's duty to the administration of justice, compelling as it is, seems, to A ustralian readers at least, remarkably familiar from the decisions justifying the continuation of an advocate's immunity from liability for negligence and there is some irony in the fact that the same arguments are used to justify both a monopoly of the right of audience and immunity from an obligation to take reasonable care in the exercise of that monopoly. 23

Further secondary arguments in support of the monopoly on the right of audience were collected by Stein JA in D amjanovic, ${ }^{24}$ such as the fact that a lay advocate is not subject to a disciplinary code, may not be liable to an order for costs, is likely to take longer in the conduct of proceedings and would not recognise a duty to the opponent. He concluded by citing $\mathrm{M}$ ahoney $\mathrm{A} P$ in another $\mathrm{N}$ ew South W ales Court of A ppeal decision, 25 where that judge formulated three guiding principles in the preservation of the restriction of the right of audience:

"First, the duty owed by counsel to the court; secondly, the possibility of unqualified advocates interfering with the course of a proceeding and causing loss and delay; and thirdly, the public interest in the effective efficient and timeous disposal of litigation: "the administration of justice requires that full assistance be available to the court in determining the issues of fact and law which come before it. The isolation of issues and the presentation of the consideration (sic) which support one answer rather than another are things best done by a person experienced in such matters." 26

These arguments will be examined more closely in Part III of this article.

Given the courts' unwavering support for the restriction of the right of audience to the profession, the question must now be asked: on what legal basis may law students (or those lay advocates who were the subject of the cases already discussed) seek to appear before the court?

The answer lies in another familiar concept: the inherent jurisdiction of every court to regulate proceedings before it. A s an element of this jurisdiction, every court has a discretion to permit any person to appear as advocate before it. This discretion was upheld by the Privy Council (on appeal from the Supreme Court of N ew South Wales) in 0 'Toole v Scott27 and has been recognised in Engl ish cases such as A bse v Smith 28 which canvassed a number of earlier English cases to the same effect. The Privy Council held that statutory provisions granting the usual right of audience to the profession did not abrogate the discretion so that, while members of the profession have a right to appear, this exists side by side with the court's general discretion to permit other persons to appear.

22 ibid at 326

23 A bse $v$ Smith was decided in 1986 not long before the enactment of the Courts and Legal Services A ct 1990 and $\mathrm{D}$ onaldson $\mathrm{M} R$ went on to say that the best way to ensure the maintenance of high standards was to limit advocacy to a relatively small group of practitioners, ie the Bar - at 327
24 note 19 above

25 Scotts H ead D evelopments Pty. L td v Pallisar Pty. L td (unreported, C ourt of A ppeal, 6 September 1994)

26 ibid at pp. 3-4

27 [1965] A C 939

28 note 7 above 
The position in Australia, therefore, is that an unqual ified advocate, such as a student, while having no right to appear, does have the right to seek the court's exercise of its discretion in granting him or her leave to appear. 29

A lthough the position is now different in England in that the discretion has been abrogated by s.27(1) C ourts and Legal Services A ct 1990, it is proposed to examine the criteria on which the common law discretion will be exercised, because it is suggested that similar criteria should be applied by courts in granting a right of audience under s.27(2)(c) of the Act.

The A ustralian cases indicate that there are two issues which arise when the court is considering whether or not to exercise its discretion and grant an unqualified advocate leave to appear.

First, should the discretion be exercised liberally or only in exceptional cases?

Secondly, is it exercised differently according to whether the proceedings in question are in the lower courts or in a superior court such as a Supreme Court?

W ith regard to the first issue, the Privy Council expressly considered the question. It concluded:

"[The discretion] can be exercised either on general grounds common to many cases or on special grounds arising in a particular case. Its exercise should not be confined to cases where there is a strict necessity; it should be regarded as proper for a magistrate to exercise the discretion in order to secure or promote convenience and expedition and efficiency in the administration of justice." 30

H owever subsequent A ustralian cases have expressed the position more narrowly. In R v Schagen 31 the Western Australian Court of Criminal Appeal permitted two students to represent an appellant who was deaf and "virtually incomprehensible" but made it plain that it was a rare and exceptional case. In G alladin Pty L td v A imnorth Pty L td 32 Perry J of the South A ustralian Supreme Court said the discretion must be carefully controlled. In D amjanovic v M aley33 Stein JA said that the authorities suggest that higher courts should be very chary at giving leave and, on the facts of the case before him, found that the circumstances relied upon by the applicant for leave to appear were not "so exceptional or special" 34 as to make it appropriate for the court to have granted leave to appear. In Scotts H ead D evelopments Pty L td v Pallisar Pty. L td 35 M ahoney A P appeared to ignore the very nature of a discretion when he acknowledged that the court had a discretion but said that the court "has long adopted the general rule that it will not allow an appearance by a person who has not been admitted to practice before it."

(H owever none of the Australian cases appear to have taken a position as extreme as that adopted by the Court of A ppeal in A bse v Smith ${ }^{36}$ where the issue was whether a solicitor should have been permitted to appear to read a statement agreed between the parties in settlement of a defamation action. N ot only did the Court of A ppeal refuse to countenance appearance by the solicitor; it also held that it was for the judges of the court collectively to decide whether or not to modify established practices.)

29 This is in marked contrast to the position in the $U$ nited States where all 50 States have introduced "Student

Practice Rules" - see Kuruc J W \& Brown R A

"Student Practice rules in the U nited States" (1994)

A ugust The Bar Examiner 40 and the A BA M odel

Student L egal A ssistance Rule

300 'T oole v Scott note 26 above at 959
31 (1993) 65 A C rim R 500

32 (1993) 60 SA SR 145

33 note 9 above

34 ibid para 87

35 note 24 above

36 note 7 above 
It appears therefore that, at least in superior courts, the discretion will be exercised only rarely. Furthermore some of the cases involve a complicating factor, that of a corporate party seeking to appear through an unqualified advocate, in breach of the established rule that corporations may conduct litigation only through a legal practitioner. It may be, therefore, that the corporate litigant carries a double burden in seeking to persuade the court to permit representation by a lay advocate.

A s to the second issue, whether the discretion will be exercised differently according to the court's place in the hierarchy, 0 'T oole $v$ Scott 37 concerned a summary prosecution in the M agistrates' Court (the lowest court in the Australian hierarchy). All the other cases discussed related to applications for leave to appear in either the District Court (the court between the M agistrates' Court and the Supreme Court) or in Supreme Courts. It may be that the Privy Council in 0 'T oole was willing to take a more relaxed view of the possibility of unqualified advocates appearing in the $\mathrm{M}$ agistrates Courts, particularly as the unqualified advocate in question was a police prosecutor.

In contrast it is not surprising, given the nature and complexity of the Supreme Courts' jurisdiction, if the judges are extremely reluctant to countenance lay advocacy.

The examination of the cases on the circumstances in which a court will grant a lay advocate leave to appear discloses no consistent criteria to guide future applicants. It would seem that an unqualified advocate seeking leave to appear would be dependent entirely upon the circumstances of the individual case and the inclination of the presiding judge or magistrate.

\section{PART II The Monash Student Appearance Program}

It is in this context of ancient legal principle and judicial discretion that the M onash U niversity clinical legal education teachers developed the "Student A ppearance Program" which after ten years has become a routine part of the clinical students' experience. This part of the article will outline the key elements in the program, the social and political context and the strategies adopted in persuading courts to accept the concept of students appearing regularly before them.

The $\mathrm{M}$ onash clinical program is based in two community legal centres. The students, in the final year of their law degree, work in the centre for a semester (five months) for credit for their degree. They are supervised by teaching staff who are qualified and experienced practitioners. Clients come from the local community.

The fundamental philosophy of the program is that students take frontline responsibility for the conduct of their clients' matters. They take initial instructions, then discuss the problem with their supervisor before returning to the client with advice. If the matter is appropriate for the centre to take on, the student opens a file and carries out all the tasks required, whether it be research, writing to the opposing party, briefing counsel etc. All the students' work is closely supervised: all letters and documents are checked by the supervisor before being typed and supervisors hold a weekly file review with each individual student to discuss the next steps to be taken, strategies to be adopted etc.

A mong the most common types of matters handled by the centres are summary criminal prosecutions and simple family law matters. D espite the existence of a public legal aid system these clients are frequently ineligible for aid.

37 note 26 above 
The legal aid system in Victoria is administered by a body formerly entitled the L egal A id Commission of Victoria (now Victoria Legal A id) established under the Victorian Legal A id A ct 1978.

The Act provides two key criteria for the granting of legal aid: a means test and a "merit" test. The "merit" provision is suitably broad: if the provision of aid is "reasonable having regard to all relevant matters": (s.24(1)). Section 24(4) provides that all relevant matters include: "the nature and extent of any benefit that may accrue to the person, to the public or to any section of the public from the provision of the assistance or of any detriment that may be suffered by the person, by the public or by any section of the public if the assistance is not provided"; and in the case of court proceedings, "whether the proceeding is likely to terminate in a manner favourable to the person".

In order to implement these legislative criteria, the Legal A id Commission formulated a detailed means test and a set of priorities and guidelines under the merit test. A lthough criminal matters are generally the first priority, within that category, for obvious reasons, priority is given to matters carrying the more serious penalties. Generally, for summary criminal matters, aid will not be granted unless the applicant faces a real risk of imprisonment or fines totalling above a certain minimum.

Although no observer could challenge these priorities, within the context of continuing constraints in the legal aid budget the result is that numbers of legal centre clients facing summary criminal or traffic charges cannot afford counsel's fee but are ineligible for legal aid.

A detailed breakdown of the number of unrepresented defendants in the $M$ agistrates court is not available, nor does the legal aid body publish statistics of applications and their outcomes in other than broad general categories. But the Legal Aid Commission of Victoria Statutory A nnual Reports for the period 1989-1992 show a sharp increase in the percentage of applications refused, from $20.5 \%$ in $1989-90$ to $26.4 \%$ in $1990-1991$ to $29.3 \%$ for $1991-1992.38$

In the area of family law, the second general area of priority for the Legal A id Commission, aid has never been available for divorce applications, which under the Commonwealth F amily Law A ct 1975 follow a simple procedure and can realistically be handled by an English-speaking applicant. H owever an applicant with language difficulties cannot be expected to present the application unassisted.

By 1992 the Family Court was beginning to speak publicly of the need for improved legal aid. In his Foreword to the Court's A nnual Report of 1991-92 the Chief Justice wrote:

"There are three major impediments to access to the court. The first of these is effective legal representation and this has been progressively diminished by the combined effects of the recession and a significant reduction in legal aid funds available in the area of family law." 39

(The legal aid situation in Australia has worsened with the intervention of the conservative Federal Government elected in 1996. TheF ederal G overnment has al ways contributed morethan $50 \%$ of total legal aid funds and the new government set about severely reducing its contribution. In 1997 the director of the U K Legal A ction G roup visiting A ustralia commented that legal aid funding in the U K amounted to $A \$ 60$ per head of population, whereas in A ustralia it amounted to $A \$ 15$ per head. $)^{40}$

38 Legal A id Commission of Victoria, Statutory A nnual Reports, 1989-1990, 1990-1991, 1991-1992, Education and Information Division Legal A id Commission of Victoria M elbourne.

39 Family Court of A ustralia, A nnual Report 1991-1992
A ustralian G overnment Publishing Service, Canberra, at $p .8$

40 cited in (1997) N ovember N SW Law Society J ournal at p. 19 
It was in this context that clinical teachers and students were seeing increasing numbers of clients in criminal and family matters who were not eligible for legal aid but who, on any reasonable view, were quite unable to represent themselves, because of their language or educational disadvantages. It was particularly frustrating for students who might have devoted a great deal of time and effort to preparing a client's case, but felt that their work was almost wasted because of the lack of competent representation. We therefore decided to embark upon a campaign to enable students to provide that representation. $\mathrm{O}$ ur objectives were both the provision of better service to our clients and the expansion of our students' educational experience.

A previous attempt to have students permitted to represent their clients had failed. We approached the Chief Justice of the Family Court with a proposal that students be granted a limited right of audience in the local registry of the Court, where the legal centres were well known to registry staff.

U nfortunately we failed to do our homework properly and al though the Chief Justice personally favoured the idea, it met with "almost universal opposition" 41 from the other members of the court, who took the view that an amendment to the relevant provision of the Court Rules would be required. $\mathrm{H}$ ad we done our research and prepared a full submission on the law and the existence of the 0 'T oole $v$ Scott42 discretion, the result might have been different, because less than three years later we received a very positive response from the Judge in charge of our region of the court.

It is possible that the change in attitude was caused by a realisation of the impact of the steady increase in the number of unrepresented litigants, particularly in the local registry. (The Registry in Dandenong, in the outer south-east of M elbourne, is generally regarded as having the highest percentage of unrepresented litigants - $40 \%$ - of any Family Court registry in A ustralia. Its catchment area includes high levels of non-English-speaking residents and socio-economic disadvantage)

$\mathrm{H}$ aving learnt our lesson from the first approach to the Family Court, we now did the research and prepared a far more detailed submission and a set of guidelines, setting out the criteria limiting the clients, cases and students to which the proposed "Student A ppearance program" might apply.

The key components of the guidelines were, and still are:

- students would appear only for clients who had no access to qualified representation (other than a legal aid Duty Lawyer);

- students would appear only in unopposed matters in the M agistrates Court and the Family Court;

- students' appearances would be 'supervised' in court by a qualified practitioner.

The guidelines have a number of underlying objectives. The restriction of student appearances to matters where the client has no access to qualified representation serves three purposes. We can say in all honesty that the client can hardly be worse off with representation by a well prepared and supervised student than if he or she had to appear unrepresented. The private profession can see that there is no risk of the program taking clients who would otherwise be paying their fees (personally or through L egal A id); and there is an obvious benefit to courts increasingly burdened with unrepresented litigants.

The restriction to unopposed matters in the $\mathrm{M}$ agistrates Court or Family Court enabled us to meet

41 Correspondence $\mathrm{H}$ on Justice $\mathrm{N}$ icholson, Chief Justice, Family C ourt of A ustralia, to the author, 13 June 1990

42 note 26 above 
the major categories of need among our legal centre clients - guilty pleas in summary criminal matters in the $\mathrm{M}$ agistrates Court and divorce applications in the Family Court where for language or other reasons the client could not reasonably be expected to present the application unaided. ( $T$ he nature of our clientele is such that we get a significant number of relatively complex divorce applications: for example, where the parties married in A fghanistan, fled to a refugee camp in Pakistan, then separated somewhere between there and Australia. The M arriage Certificate is lost and a new one cannot be obtained because the equival ent of the Registry of Births Deaths and $M$ arriages in Kabul has been bombed by one side or another. The client has not seen her husband for two years and, as refugees, there may not be any family members in Australia on whom substituted service of the application may be effected. Cases such as these provide a wonderful learning experience for the student and if he or she has been responsible for the preparation of all the documents necessary to support the application, the opportunity to present the application in court as the culmination of his or her work provides a remarkable sense of achievement.)

Cases in these categories are most likely to be ineligible for legal aid and therefore meet the "no other access to representation" criterion. Furthermore, they are by their nature able to be prepared fully in advance - the possibility of ambush by an opposing party is minimal or non-existent and, as most legal centre supervisors are solicitors rather than barristers, we are thoroughly confident of our ability to prepare our students for these cases.

The third critical element in the guidelines, that a student would be "supervised" in court by a qualified practitioner, provides the reassurance of someone who could step in and take over if something went wrong (although this has never been necessary).

A final element which we regard as important is that, as teaching staff, we take responsibility for assessing whether an individual student is competent to appear. There is no expectation that every student enrolled in the clinical subject will have the opportunity to appear.

Having prepared the explanation of the law and the guidelines, we laid the groundwork in other ways before approaching the courts. We decided it would be important to have the support of, or at least no active opposition from, the profession. The Law Institute (the equivalent of the Law Society) was remarkably positive, its Council voting unanimously to support our proposal. 43

The Victorian Bar Council referred the proposal to several sub-committees, wrote several expositions of the relevant legal issues and then concluded that it was a matter for the courts. ${ }^{44}$

At the same time, we asked those of our students who had accompanied a client to court as a $M$ cKenzie friend, or represented a client in a tribunal, to write brief accounts of their experience The purpose was to attach these accounts to our submission to the M agistrates Court, to illustrate in concrete terms the types of cases in which we proposed students should be allowed to appear and to provide preliminary evidence that our students were indeed competent in "lower level matters". (Several students who had gone to court as a McKenzie friend were asked by the $M$ agistrate to speak on behalf of the client and had acquitted themselves well, despite the fact that they had not expected to represent the client in this way and had therefore not prepared for it.)

The proposal was finally ready to be submitted to the $C$ hief $M$ agistrate. (A fter our false start with the Family Court we decided to begin this time with the Magistrates Court.) We included

43 Council of the Law Institute of Victoria, $21 \mathrm{~N}$ ovember 1991
44 Correspondence A J K irkham, QC, Chairman, Victorian Bar C ouncil, to the author, 8 and 14 M ay 1992 
information on the clinical program and described the Student A ppearance proposal as 'the logical extension of our existing course'. The proposal was considered by the Council of M agistrates and received the support of the 'overwhelming majority'. ${ }^{45} \mathrm{~A}$ very small minority expressed strong disagreement and of course the Chief $M$ agistrate, who personally supported it, could not direct her colleagues in the exercise of their discretion.

W e then submitted the proposal to the Judge A dministrator of our region of the Family Court. $W$ ithin a month the $C$ hief Justice and Southern Region Judges gave their support and the program began at the beginning of 1993.

\section{The process}

O nce the clinic supervisor has identified a case as meeting the guidelines and the student wants to represent the client, the program is explained to the client, who of course is free to decide either to represent him or herself or to rely on a D uty Lawyer. If the client wants the student to represent him or her, s/he is asked to sign a form of consent. This includes an acknowledgement that the client is aware that the student is not a qualified lawyer. This form can be produced to the court if required and is placed on the client's file after the hearing.

The student is then responsible for preparing the matter fully. M ost teachers require their students to prepare a complete "script", which the teacher then checks, but the student is of course told that on no account are they to read their script in court. The objective is that the student knows the facts, the law and the procedure so thoroughly that they can answer any question put to them, preferably without reference to their notes. (In this respect it is easy to understand that a student's performance may be much more competent than a junior barrister who has received the brief only the night before the hearing.)

In the early years of the program, clinic teachers tried to act as the in-court supervisor of their students wherever possible. As the program became more routine and we became more confident of the courts' attitude, we have tended to arrange for other practitioners, barristers or legal aid lawyers, to act as in court supervisors.

On the day of the hearing when the student checks in with the court office, s/he informs the court co-ordinator that it is a student appearance and this is noted on the court file This means that when the case is called the $\mathrm{M}$ agistrate or Registrar can see that a student is representing the client. A II the student has to do is formally to seek leave to appear on behalf of the relevant party. From then on the case proceeds as normal.

\section{A ssessment}

Initially we had not intended that appearances would be assessable. However, it quickly became apparent that the students put so much work into their preparation, in a subject which itself required significantly more work than a conventional academic subject, that fairness required that they be allowed to count appearances as part of their assessment.

We therefore introduced a regime that allowed students to choose, for $20 \%$ of the total mark in the clinical subject, either an assignment (which had previously been mandatory) or two

45 C orrespondence M s Sally Brown, C hief M agistrate, M agistrates C ourt of Victoria, to the author, 21 January 1993 
appearances and a 1000 word report. The elements of assessment for the appearances themselves are: prehearing preparation; adherence to rules of court etiquette; content of appearance; and after-court explanation to the client.

For the report, the student is required to compare the two appearances in respect of issues such as preparation, supervisor's role, how the clients felt about being represented by a student; ethical issues and what they learnt from the experience.

The introduction of assessment into the program added an additional practical factor - the in-court supervisor would be asked to complete the assessment form. ${ }^{46} \mathrm{H}$ owever as the majority of supervisors are more than willing to give students detailed feedback this has not proved to be a difficulty.

Secondly when a student has done one appearance and therefore opted for this form of assessment there is some pressure on the clinic supervisor to "find" a second appearance for that student. The teacher's responsibility to balance the interests of clients and students is discussed more fully below.

\section{M agistrates' attitude}

Given that a small number of $M$ agistrates had made it known in advance that they opposed the program we have experienced very few difficulties. A record was kept of every appearance in the first few years and when an individual $M$ agistrate refused leave to a student, all teachers tried in subsequent cases to ensure that a case was not heard before that $M$ agistrate. Some $M$ agistrates who refused leave in the first case that came before them eventually changed their mind and granted leave in later cases without demur.

\section{Evaluating the students' performance}

In the ten years since the program began students have represented more than 1,000 clients who would otherwise have gone unrepresented.

No systematic evaluation of the quality of the students' performance has been carried out but the marks awarded by practitioners who act as in-court supervisors indicate a high level of competence. In one semester the average mark given by external supervisors was $87.5 \%$.

In a research project recently completed by the author and Judith Dickson of LaTrobe U niversity, ${ }^{47}$ magistrates who had presided over, and practitioners who had supervised, at least two appearances were interviewed about their views of the program. The magistrates were clearly very positive. They supported the program because of its educational value to students; they thought that the students' performance was generally as good as that of junior practitioners and that they assisted the court.

Similarly the practitioners interviewed considered that the students they had seen were often as good as and sometimes better than junior practitioners, mainly because the students had obviously prepared so thoroughly; and one said the students were of a very high standard. The practitioners all agreed that the representation provided by the students was much more efficient in the court process than an unrepresented defendant.

46 on one occasion, when the author was in-court supervisor for one of her students, when the student had finished her plea, the M agistrate looked across and said "Well M rs Campbell, you would have to give her 10 out of 10 for that". The thought of giving the magistrates the assessment form to complete flashed briefly through our minds.
47 Dickson, J and Campbell, S, Student A dvocacy in A ustralian Courts: Recommendations for a M odel Program, Report to the Commonwealth A ttorney$G$ eneral's D epartment, September 2003. It is hoped to publish an article based on this project in the near future. 
Clients' views of the service they received from the students have not been recorded other than anecdotally. It is probable that most clients, who had become used to dealing with a student during the conduct of their matter in the legal centre, took it for granted when the same student represented them. Clients were therefore not particularly concerned by the legal significance of having a student represent them, even though they had had this aspect brought to their attention when the consent form was explained to them.

\section{The role of the clinic supervisor}

The clinic supervisors play a dual role: they are teachers and practitioners. In all the work of the legal centres in which students are involved, they have a dual responsibility - to protect the client's interest in receiving competent legal service and the student's interest in expanding their educational experience. The supervisor must constantly weigh and balance the two interests. This requires a careful assessment of the legal tasks which must be carried out and the timeframe within which this must be done, in order to advance the client's position; and an equally careful assessment of the competence of the individual student and their capacity to meet the relevant timeframe. The student will learn more if they are given the responsibility and the opportunity to perform the work required; but the client will suffer if the student cannot competently complete it within time. Into this mix the supervisor must add their own availability - to be accessible to advise the student and to check their work.

The same process applies within the specific context of the student appearance program. W hen a client comes into the legal centre with, for example, a summary criminal matter, the supervisor must assess a number of interlocking factors:

- should the client plead guilty or not guilty? If the plea is not guilty, the matter will not be within the program guidelines;

- might the client be eligible for legal aid? If so, again the case is outside the guidelines;

- is there time to make an application for legal aid?

- even if the appropriate plea is guilty, is the case appropriate for student representation, bearing in mind the seriousness of the charge, the client's prior history etc? These factors might on reflection strengthen an application for legal aid.

- If the case is appropriate for student representation, is the individual student who has interviewed the client and taken on the conduct of the matter competent to do it?

In this complex formula the supervisor must be careful to put aside the consideration, mentioned earlier, that the student "needs a second appearance".

The supervisor identifies and articulates these factors in discussion with the student. In so doing the supervisor is modelling for the student the careful professional attitude of putting the client's interest first and acknowledging the ethical obligations inherent in the lawyer's role.

The more substantial aspect of the supervisor's role in the student appearance program relates to the student's preparation for the appearance. With every appearance, the reputation of the program is at stake and the supervisor must provide the student with advice, support and the 
appropriate sense of responsibility for the client; while not burdening him or her with the added responsibility of the fate of the whole program.

From the moment that the question of student representation is discussed throughout the preparation of the appearance, the supervisor helps the student to identify the ethical issues involved: the duty to put the client's case, the duty not to mislead the court. W hat can be said on behalf of the client? W hat must not be said?

\section{Part III Can student appearances meet the policies underlying the limited right of audience?}

Can a Student A ppearance program, operating within the guidelines discussed earlier, meet the justifications put forward by the courts for the restriction of the right of audience to qualified practitioners?

There is no doubt that, as long as the emphasis is on the formal status of admitted practitioners, students do not have that status. But can they meet the substance of the courts' requirements?

It is suggested that, provided students' appearances are confined to limited categories of cases and clinic supervisors continue to take full responsibility for their thorough preparation, they do in fact meet the major requirements.

The critical issue is that ex hypothesi the alternative to student representation is litigants in person. There can be no doubt that a well prepared student is far more likely, in the words of $M$ ahoney A P, to provide "full assistance to the court...in the isolation of issues and the presentation of considerations which support one answer rather than another." $48 \mathrm{~W}$ hether in a guilty plea or a family law application the student presents the facts relevantly and concisely, identifies the legal issues and articulates the outcomes sought. It is virtually impossible for the overwhelming majority of litigants in person to do this.

Secondly the clinic supervisors ensure that students are extremely conscious of their duty to the court and considerable care is taken in the preparation of the appearance to ensure that this duty is fulfilled. A lthough the litigant in person has a duty not to mislead the court 49 it is asking a great deal of the average person that they resist the temptation to cross the fine line between putting the truth as favourably as possible and exaggerating or embellishing it.

Thirdly, the role of any advocate, qualified or not, includes controlling the anxious or temperamental litigant who, in the absence of the sense that their story is being told and heard, might well disrupt the proceedings by outbursts or abuse.

The one consideration underlying the restricted right of audience which student appearances cannot meet is the availability of disciplinary sanctions over practitioners who fail to meet their ethical obligations. The very fact that students are not admitted to practice makes this self-evident (although presumably if a student's conduct were inappropriate in the extreme they could be held in contempt of court).

It is to meet this issue that the research project referred to above, in proposing model legislation governing student advocacy, recommends that a provision be included imposing "the same duties

48 Scotts H ead D evelopments Pty. L td v Pallisar, note 24 above
49 Vernon v Bosley (N 0.2) [1997] 1 A II ER 614 per StuartSmith LJ at p.629 
and obligations" on student advocates as if they were qualified practitioners.

The final issue to be considered is whether a student could "cause the litigant loss" and this leads to a discussion of whether a student advocate would be liable to a client in negligence.

\section{PART IV A student immunity?}

The applicable authority in Australia on the advocate's immunity from liability for negligent incourt conduct is the decision of the $\mathrm{H}$ igh Court of Australia in G iannarelli $v$ W raith 50 where by a $4 / 3$ majority the Court upheld the immunity, following the same reasoning as Rondel $v$ W orsley51 and Saif A li v Sydney M itchell \& C 0.52

In 199953 the High Court was expressly invited to reconsider its decision in G iannarelli v W raith. ${ }^{54}$ In a decision handed down seven months before that of the House of Lords in A rthur J.S. H all \& C 0. Ltd. v Simons, 55 effectively abolishing the immunity, the Court rejected the invitation. The practitioners who were defendants to the claims in this case were held not to have been negligent and the Court was therefore able to put aside the issue of advocates' immunity on the basis that it did not need to be considered.

However there were indications from three judges that on "another day" 56 the issue might be reconsidered. G audron J (since retired) said that had the question of "immunity" arisen, she would have granted leave to re-open G iannarelli because proximity - "more precisely the nature of the relationship mandated by that notion - may exclude the existence of a duty of care on the part of legal practitioners with respect to work in court." 57 Gummow J acknowledged that a number of issues arise with respect to the immunity. ${ }^{58} \mathrm{~K}$ irby $\mathrm{J}$ devoted a significant part of his judgment to the policy issues relevant to the immunity and said that the binding authority of Giannarelli is confined to immunity in respect of in-court conduct. 59

It therefore seems likely that the issue of the immunity will be re-opened by the High Court in a case where it cannot be avoided.

However, as long as G iannarelli v W raith remains the applicable law in A ustralia, it is necessary to analyse the reasoning in that decision in an attempt to answer the question of whether students as advocates might also be immune from liability for any negligence in the conduct of the matter in court.

The plaintiffs in Giannarelli were three men who had been convicted of perjury as a result of evidence they gave to a Royal Commission. The negligence complained of against their counsel was that the latter failed to raise in the plaintiffs' defence of the perjury proceedings provisions of the Commonwealth Royal Commissions Act 1902 which rendered evidence given to a Royal Commission inadmissible in criminal proceedings. There could perhaps be no clearer example of professional negligence

50 (1987-1988) 165 CLR 543

51 [1969] 1 A C 191

52 [1980] A C 198

53 Boland $v$ Yates Property Corporation Pty. Ltd and A nother 167 A L R 575

54 note 49 above
55 [2002] 1 A C 665

56 Boland note 52 above at p.604 para 116

57 ibid p.602 para 107

58 ibid p.603-4 paras 113-114

59 ibid p. 618 para 150 
The leading judgment in the High Court is that of M ason CJ. A fter referring to Rondel v Worsley's60 rejection of the argument that a barrister's inability to sue for his fees could support his immunity in negligence, the Chief Justice went on to support the maintenance of the immunity on two considerations of public policy. The first is counsel's duty to the court, which overrides the duty to the client but which might be threatened by counsel's concern to avoid the risk of a negligence action by the client. The second consideration is the "relitigation" argument, that an action for negligence would constitute a collateral attack on the decision in the principal case. ${ }^{61}$

Leaving aside the merits of these arguments, which have been dealt with persuasively by the House of Lords, the question becomes: can such considerations of public policy apply equally to unqualified advocates appearing by leave of the court?

It is clear that the "relitigation" argument can logically apply with equal force to cases conducted by a lay advocate and those conducted by an admitted practitioner, because it is an argument based not on the status of the advocate or even on his or her role, but one based on the efficient operation of the system, the administration of justice in the abstract. 62

A s to the first ground of public policy, that the risk of being sued for negligence by the client might influence the advocate's conduct of the case at the expense of his or her duty to exercise independent judgment in the interest of the court, prima facie it might be concluded that the immunity could not apply to unqualified advocates simply because they do not owe a duty to the court as qualified advocates do. The justification for the immunity would therefore not apply to unqualified advocates. A nd it is probably no answer to this argument to say that, in seeking leave to appear, the unqualified advocate voluntarily assumes the duty imposed upon qualified advocates by virtue of their status as officers of the court.

However analysis of this justification for the immunity at a deeper level produces another issue Is the immunity in fact based upon the advocate's status or upon the function he or she fulfils in the conduct of litigation? If it is based upon the advocate's status as a person admitted to a regulated profession who is subject to prescribed disciplinary sanctions for unacceptable conduct, then there can be no basis for extending the immunity to unqualified advocates.

A Iternatively, if the immunity is justified on the basis of the function the advocate performs within the system of justice, then there may be no reason why any person carrying out this function with the permission of the court should not be covered by the immunity.

A close analysis of the majority judgments in G iannarelli $v$ W raith suggests that this may well be the case. The judgments refer throughout to the advocate's role in assisting the administration of justice, to counsel exercising an independent judgment "in the interests of the court".63 For example, $\mathrm{M}$ ason $\mathrm{CJ}$ said:

"It follows that the exposure of counsel to liability in negligence for breach of a common law duty of care would create a real risk of adverse consequences for the efficient administration of justice Litigation would tend to become more lengthy, more complex and more costly." 64

60 note 50 above

61 G iannarelli v W raith note 49 above at p.555

62 It is also an argument which ignores the fact that the capacity of a disappointed litigant to sue his or her solicitor for negligence in the preparation of the case has exactly the same consequences of relitigating, 'tarnishing' the earlier decision and bringing the administration of justice into disrepute - per Wilson J at 574.

63 G iannarelli v W raith note 49 above at p.557

64 id 
Brennan J said:

"If the immunity of counsel were abrogated, the assistance which courts obtain from the advocacy of an independent profession would be imperilled." 65

The point is reinforced by the court's acceptance that the immunity extends to a solicitor/advocate A s Wilson J said,

"The critical factors are the function (the advocate) is performing at the material time and the impact which non-recognition of immunity might have upon the administration of justice It is the function of advocacy that attracts the immunity, (emphasis added) and, accordingly, it matters little whether the advocate is admitted to practice as a solicitor or as a barrister or as both." 66

If it is accepted that the immunity exists to protect the advocate's role in the administration of justice, then it is at least arguable that an unqualified advocate should also benefit from the immunity, at least where the litigant would otherwise be unrepresented. The unqualified advocate is given leave to appear precisely because the courts accept that they are assisted by the appearance of an advocate who is able to present the litigant's case clearly, concisely and honestly.

In theory, therefore, the M onash students might be protected by the immunity. O $\mathrm{n}$ the other hand, the argument that the advocate is entitled to immunity because of the role he or she plays in assisting the court and therefore advancing the administration of justice would not necessarily apply to all unqualified advocates, such as those who feature in cases such as Paragon Finance plc v N oueiri67 and R v L eicester C ity Justices ex p Barrow. 68

But it is difficult to see how the courts could draw a distinction between the unqualified advocate operating within a program which ensures car eful supervision and preparation, and those who seek to appear without such endorsement. It would not be acceptable to apply the immunity on a case by case basis.

Furthermore, given the criticism which the immunity attracts, acknowledged by the House of Lords 69 and by the minority judges in $G$ iannarelli $v$ W raith, 70 it is unlikely in the extreme that the High Court would extend the immunity, no matter how strictly logical the argument.

Consequently the $\mathrm{M}$ onash program has never relied upon the possibility of its students being protected by the immunity. Instead we rely upon more pragmatic considerations: the fact that, in

65 ibid at p.579

66 ibid at p. 577

67 [2001] 1 W LR 2357 per Brooke LJ at 2363, quoting Judge LJ in another case involving the same lay advocate: 'The courts from the master to the $\mathrm{H}$ ouse of Lords have been inundated with a series of applications by $\mathrm{M} r \mathrm{~A}$ lexander which have ultimately proved to be illfounded. Time and again the exercise has been pointless and wasteful of limited court resources and from time to time has involved the defendants in additional expense."

68 note 13 above, where Watkins LJ said (at p.271): "Increasingly justices are being placed in the intolerable position of being faced with people claiming to be friends of defendants who are either politically motivated or activists opposing some authority or other whose function it is to carry out the wishes of Parliament."

69 A rthur J S Hall \& C O. L td v Simons note 54 above per L ord Steyn at p. 678

70 note 49 above, per D eane J : "I do not consider that the considerations of public policy which are expounded in Rondel $v$ Worsley and in the majority judgments in the present case outweigh or even balance the injustice and consequent public detriment involved in depriving a person, who is caught up in litigation and engages the professional services of a legal practitioner, of all redress under the common law for 'in court' negligence, however gross and callous in its nature or devastating in its consequences" at p.588 
the categories of cases in which students appear, it is highly unlikely that a client would suffer any provable "Ioss" which could be attributed to a student's conduct; and the assumption that a client who wished to sue would be advised to sue either the in-court supervisor, or the clinic supervisor and the $U$ niversity, all of whom are covered by professional indemnity insurance.

But ultimately we rely upon careful selection of cases and students and meticulous preparation of the content of the appearance.

\section{Conclusion}

In an ideal system every litigant would be represented by qualified and competent counsel.

But as long as the public legal aid system does not fulfil this ideal, law students can play a small but important role in filling the gap. If a system is established which ensures a certain minimum level of competence the courts as well as the litigants will benefit and the students' education will be enriched.

Legislative provision would regularise the concept, define the parameters within which students could appear and establish a minimum threshold of ethical responsibility in the interests of the litigant and the administration of justice. 